\title{
A STUDY OF JOHN BUNYAN
}

VarIous causes conspire to make Bunyan's spiritual history one of peculiar interest, and also one which especially lends itself to psychological study in present times. Not only is his claim to rank among the geniuses of religion undisputed, but Pilgrim's Progress testifies to natural literary endowments of an uncommon order, and his life, though he began in a village farrier's shop, was spent in the hurly-burly of public interests and affairs. He has been fortunate, moreover, to find in the Rev. John Brown and in Mark Rutherford biographers of exceptional merit, and in Macaulay a critic of acknowledged gifts. Finally, he has left us in Grace Abounding to the Chief of Sinners a personal record, which provides us with ample and detailed evidence (except in the matter of dates) of his profoundest inward experiences. The contrast between this testimony and Macaulay's account of the same facts reveals, with impressive clearness, the differentia of religious experience.

Macaulay's attitude to the supernatural element in Bunyan's experience is so typical of Whig philosophy in every age, that it may well be quoted at some length. The passage comes from the early pages of the Essay on Bunyan, which was written originally in 1854 for the eighth and ninth editions of the Encyclopoedia Britannica.

\footnotetext{
"It has long been an ordinary practice with pious writers to cite Bunyan as an instance of the supernatural power of divine grace to rescue the human soul from the lowest depths of wickedness. He is called in one book the most notorious of profligates; in another, the brand plucked from the burning. He is designated in Mr. Irvine's History of the Baptists as the depraved Bunyan, the wicked tinker of Elstow. . . . But whoever takes the trouble to examine the evidence will find that the good men who wrote thus had been deceived by a phraseology which, as they had been hearing it and using it all their lives, they ought to have understood better. There cannot be a greater mistake than to infer, from the strong expressions in which a devout man bemoans his exceeding sinfulness, that he had led a worse life than his neighbours. . . . It is quite certain that Bunyan was, at eighteen, what, in any but the most austerely puritanical circles, would have been considered as a young man of singular gravity and innocence. . . . He declares, it is true, that he had let loose the reins on the neck of his lusts, that he had delighted in all transgressions against the divine law, and that he had been the ringleader of the youth of Elstow in all manner of vice. But, when those who wished him ill accused him of licentious amours, he called on God and the angels to attest his purity. No woman, he said, in heaven, earth, or hell, could charge him with having ever made any improper advances to her. Not only had he been strictly faithful to his wife; but he had even
} 
before his marriage been perfectly spotless. It does not appear from his own confessions, or from the railings of his enemies, that he ever was drunk in his life. One bad habit he contracted, that of using profane language; but he tells us that a single reproof cured him so effectually that he never offended again. The worst that can be laid to the charge of this poor youth, whom it has been the fashion to represent as the most desperate of reprobates, as a village Rochester, is that he had a great liking for some diversions, quite harmless in themselves, but condemned by the rigid precisians among whom he lived, and for whose opinion he had a great respect. The four chief sins of which he was guilty were dancing, ringing the bells of the parish church, playing at tip-cat, and reading the history of Sir Bevis of Southampton. A rector of the school of Laud would have held such a young man up to the whole parish as a model. But Bunyan's notions of good and evil had been learned in a very different school; and he was made miserable by the conflict between his tastes and his scruples."*

In this passage Macaulay has set himself to whitewash Bunyan, and has no doubt succeeded to his own satisfaction; but he has done it in a way which shows that he has entirely missed the significance of what he is describing. He cannot conceive of the problem of conduct as more than the problem of particular actions, nor of serious sin, except in connection with intemperance or sexual unchastity. We are given to suppose that the case is one of a youth of strong natural virtues and sensitive conscience, who allowed himself to be narrowed and embittered by the society of " rigid precisians" in which he lived. It would be difficult on this hypothesis to guess how, from this unlikely soil, should have sprung the work which has placed Bunyan among the Immortals.

Bunyan's own testimony to what occurred is very different; and, fortunately, modern psychology enables us to understand his spiritual autobiography more richly than heretofore. Indeed, the record of inward conflict in Grace Abounding provides illustration of all the main features now recognized as symptomatic of the different types of conversion. The theory I shall follow in dealing with it, and the terminology I shall use, are taken from two striking articles by a contemporary psychologist, Mr. Robert H. Thouless.† Accepting Mr. Thouless's classification of conversion experiences into (1) adolescent conversions, (2) normal adult conversions, and (3) mystical conversions, we note that Bunyan experienced certainly the last two, and possibly all three. Doubt exists as regards the first, because it is not clear that the spiritual conflict of his early (tenth and eleventh) years did, in fact, ever come to a head; and the case is complicated throughout, because the

* Five Essays, by Lord Macaulay, pp. 28-30 (G. Bell and Sons, 1914).

$\dagger$ See Thrology, I. 327 ff.; II. 67 ff. 
conflict proper to mystical conversion, which occupies the whole second half of the record, also underlay and interpenetrated the simpler moral conflict of his normal adult conversion. This fact, while it adds difficulty to the analysis, makes the case one of exceptional significance.

Of the earliest stage the most striking symptom is the fearful dreams and nightmares which the child suffered in sleep, and in which the torments of hell figured largely. As he outgrew these, and entered more and more into the life of his fellow lads at Elstow, he contracted a strong resistance to religion: "I could neither endure it myself," he says, " nor that any other should "; though even then he was subject to extreme painful emotion, if he heard or saw wrong-doing in someone who made profession of piety. It does not seem, however, that this adolescent conflict was ever resolved.

At the age of twenty-one Bunyan married. His wife had been religiously brought up, introduced him to two books of devotion, and got him to go regularly to church. The dignity and order of liturgical worship made a strong appeal to him, and evidently satisfied some part of those instincts constituting the " complex" with which he was unwittingly wrestling. One Sunday he was deeply moved by the parson's sermon on Sabbath observance, which he felt to be directed at himself; and this was followed by a vivid audition and vision, while he was playing tip-cat on the same afternoon. The effect was very striking. He concluded that there was no hope for him, and that he "had as good be damned for many sins as be damned for few"; and he "returned desperately" to his sport again. This he did for a month, when two further experiences supervened. A loose woman who heard him swearing rebuked him, and thereafter he gave up the profane language, which had been his chief outward fault: and a poor man whom he chanced to meet turned him to Bible-reading, with the result that he undertook seriously to reform himself.

"Thus I continued about a year; all which time our neighbours did take me to be a very godly man, a new religious man, and did marvel much to see such a great and famous alteration in my life and manners; and indeed so it was, though I knew not Christ, nor grace, nor faith, nor hope; for, as I have well seen since, had I then died, my state had been most fearful."

He adds that his neighbours' praises pleased him well. "I was proud of my godliness, and, indeed, I did all I did, either to be seen of, or to be well spoken of by, men: and thus I continued for about a twelvemonth or more."

I take this change in the neighbours' attitude as marking 
the climax of the second stage of Bunyan's conflict-the stage roughly corresponding to normal adult conversion. It is of interest to our present purpose for several reasons. In the first place, it appears to represent precisely that level of experience and life which alone Macaulay shows himself able to appreciate in his Essay. He had become a respectable person. Secondly, of the three elements-the intellectual, the moral, and the social-which tend to give predominant colour to conversion experiences, the two last are strongly represented, and appear to reach a provisional satisfaction: the moral element in the decisive abandonment of profanity, the social in the fellowship of the respectable neighbours. The intellectual alone is unsatisfied, showing itself as an occasional irritant, as in the question whether he were one of the true Israelites to whom the promises were made. It is this intellectual element which acts as a sign-post to our third point-viz., that this stage exhibits unmistakable intimations of those deeper levels of experience which Bunyan was to pass through in the course of the mystical conflict still before him. Had the story recorded in Grace Abounding stopped short with Bunyan's entry into pious society, we should still have a valuable document of religious experience; but we should never have had Pilgrim's Progress. For that work presupposes an insight such as only comes through spiritual conflict and temptation. We may thank God that Bunyan was not as Macaulay portrayed him.

The abandonment of such innocent pursuits as bell-ringing and dancing seems to provide the natural introduction to the third and longest stage of Bunyan's conflict; since, as Mr. Thouless points out, a marked feature of mystical conversion is " the indiscriminate repression of human activities which other people regard as good with those which are generally considered bad." Moral justification of this conduct is often difficult to discover; but it seems probable that in Bunyan's case two elements combined to cause it. One was the reaction against the associations connected in his mind with these entertainments. The other was a more subtle influence. It is evident that one of the strongest constituents of Bunyan's religious complex was the emotion of fear; and the slender allusions which he makes to his childhood are sufficient to make it probable that "the fear of God" had been impressed on him during his upbringing in that stark fashion so characteristic of seventeenth-century Puritanism. Clearly, too, this element of fear had much to do with his decision to abandon bellringing; his dread of the bell or the steeple falling, while he only watched the bells being rung, attests so much. It is not unlikely that such anxieties had presented themselves to 
Bunyan, only to be sternly repressed, when he first began to handle the ropes; and it would thus not be surprising that, when his religious sentiments became active, the fear which played so large a part in them should awaken those other close-lying fears which he had striven to drive away.

Be that as it may, Bunyan now enters upon a period of acute mental and spiritual conflict. The struggle is essentially not one between good and evil, but between Nature and Supernature; between the natural man and the man new-born in Christ. What he seeks is not a unification of sentiments and impulses on the natural level - that he already had; but a unification wholly on the level of grace, a thorough interpenetration of his own personality by Jesus Christ. This consummation is symbolized for him in different religious terms; now it is Faith, now Calling, now Pardon, now Election. And particular interest attaches to the " resistances" which prevented this complex passing into conscious experience. Allusion has already been made to the fact that Bunyan's moral conversion found him with an acute intellectual problem still unsolved. Similarly, throughout the third period, intellectual questionings account for a large part of the conflict. Indeed, Bunyan provides a significant warning of the mischief which a distorted theology may do. Unable to assure himself that he had fulfilled the scriptural conditions of salvation, he fell into agonies of doubt and despair; broke into violent blasphemies of thought; desired to commit, and for a long time believed that he had committed, the unforgivable sin. Yet beneath the strange jargon of Puritan argumentation, it is evident that there was a real clash of elemental spiritual forces-himself and God. The unspoken blasphemies are the index of a heart in which self-assertion and pride are still potently operative. And, as the kindred experience of Bishop Butler shows, they are a temptation to which the highest spiritual natures are peculiarly prone. They are of a piece with the fact, pointed out by Baron von Hügel, that for Christians " Pride or self-sufficiency is the central, typical sin." Bunyan always appears as struggling against the least relic or vestige of self-sufficiency, and striving to be God-determined wholly and only. It was these vestiges of pride which seemed to be revealed in what he poignantly calls "those sentences that stood against me"; which made it so dangerous to abide in any of those "rests" which God had given him on his pilgrimage to the Infinite, and which were finally subdued and sublimated when he came to see that his only righteousness was Jesus Christ, " the same yesterday, to-day, and for ever."

"Now did my chains fall off my legs indeed; I was loosed 
from my afflictions and irons; my temptations also fled away: so that from that time those dreadful Scriptures of God left off to trouble me: now went I also home rejoicing, for the grace and love of God. ... Here, therefore, I lived for some time, very sweetly at peace with God through Christ; oh, methought, Christ! Christ! there was nothing but Christ that was before my eyes. I was not now (only) for looking upon this and the other benefits of Christ apart, as of His blood, burial, or resurrection, but considering Him as a whole Christ; as He in whom all these, and all other His virtues, relations, offices, and operations met together, and that $\mathrm{He}$ sat on the right hand of God in heaven. ... Further, the Lord did also lead me into the mystery of union with the Son of God, that I was joined to Him, 'that I was flesh of His flesh, and bone of His bone,' and now was that word of St. Paul sweet to me. By this also was my faith in Him, as my righteousness, the more confirmed in me; for if $\mathrm{He}$ and $\mathrm{I}$ were one, then His righteousness was mine, His merits mine, His victory also mine. Now could I see myself in heaven and earth at once; in heaven by my Christ, by my head, by my righteousness and life, though on earth by my body and person."

So was prepared the soul of the man who was to illuminate for all time the road of those who are pilgrims to the Celestial City.

We have studied this example of religious experience in such detail, not because it is typical of normal Christian experience, but because the contrast between Macaulay's and Bunyan's accounts of the same history sets in so clear a light the " new facts," as William James calls them, which religion introduces. We cannot here pause to consider the interpretation which sees in these "new facts" nothing but the phenomena of auto-suggestion or of herd-suggestion. Whatever be the upshot of that discussion, it is evident that Macaulay and Bunyan are working along different levels of experience, in which the same external occurrences have a completely different significance. For the former they belong to a series in time and place, whose meaning is completely weighed in the balances of social utility: for the latter, time and place are like the screen on which pictures are thrown by a magic-lantern; the real work is going on behind in the dark, where the Great Operator with muffed lantern sets human experience against " the white radiance of eternity."

Meanwhile, there is another aspect of Bunyan's spiritual conflict which may fitly serve as introduction to the concluding section of this article. To those who regard religion as purely 
subjective this much truth may be at once conceded, that in all religious experience suggestion plays an important part. The well-known influence of preaching in effecting adolescent conversion is an example of this; and we have seen how Bunyan, though then past the age of adolescence, was impressed by one sermon of his parish priest. But preaching is only one of the instruments or channels through which suggestion is exercised. It seems not improbable that, if the evidence were carefully examined, all conversion experiences would be found to be mediated from, and to, some kind of religious group and community. Often the individual is so preoccupied with their transcendent effects that he abstracts from the spiritual experience of his neighbours, and believes himself to be the sole recipient of the grace which he experiences. There are strong traces of this in Grace Abounding, but other things can be read between the lines. Of the influence of his home and schooling we know little; but we have seen how he was affected by his wife and her two books, by the Church services and ritual, by the loose woman's rebuke, and by the poor man who turned him towards Bible-reading. One may wonder whether the magnificent ceremonial of the entry to the Celestial City in Pilgrim's Progress may not be a transfiguration of experiences first met with in his parish church. But there are other contacts with the Christian community apparently more decisive for his spiritual history; and we may well attend to these.

1. I take first the meeting in Bedford with "three or four poor women sitting at a door, in the sun, talking about the things of God. . . . And, methought, they spake as if joy did make them speak; they spake with such pleasantness of Scripture language and with such appearance of grace in all they said, that they were to me as if they had found a new world; as if they were "people that dwelt alone, and were not to be reckoned among their neighbours." The immediate result of this meeting was greatly to deepen the inwardness of Bunyan's religion. He began to take notice of " secret thoughts," "to look into the Bible with new eyes," and to rid himself of bad company. Finally, his experience was reproduced and universalized " in a kind of vision." He saw " as if they were on the sunny side of some high mountain," while he was "shivering and shrinking in the cold, afflicted with frost, snow, and dark clouds," separated from them by a wall. At last he descried in the wall a narrow gap, through which, after many failures, he "went and sat down in the midst of them, and so was comforted with the light and heat of their sun." And his interpretation of the vision was that " the mountain signified the Church of the living God; the sun that shone thereon, the 
comfortable shining of His merciful face on them that were therein; the wall I thought was the world, that did make separation between the Christians and the world; and the gap which was in the wall I thought was Jesus Christ, who is the way to God the Father."

The psychologist will be interested in tracing here the materials of the vision in preceding experience, and in pointing out how the meeting with the women, the separation from worldly companions, and the reading of the Bible (particularly if it were of the last three chapters of the Revelation) seem to provide these. For our present purpose, the point I wish to stress is the operation of the social element in the spiritual experience. It is the four joyful Christians who occasion the process which culminates in the vision; and the end of the vision is the welcoming of the subject into fellowship with " the Church of the living God."

2. Unfortunately, not all Bunyan's contact with the Christian community was as happy as this. The dominating influence during the years of Bunyan's spiritual conflict was the personality and preaching of Mr. Gifford. The career of this remarkable man makes astonishing reading to-day. A man of Kent, he fought as a major in the Royalist Army, which in 1648 won back the southern part of the county to the King. At Maidstone, where Fairfax inflicted signal defeat on this force, he was taken prisoner and condemned to death. On the eve of execution he escaped from gaol by the aid of his sister, and made his way in disguise, first to London, and then to Bedford, where he practised as a doctor and was notorious for his loose life. Before long, however, he was converted, attached himself to the Congregational body, and became the pastor of their little community. In 1653 the benefice of St. John the Baptist, Bedford, falling vacant, the mayor and corporation, in whose gift it lay, presented Gifford to the living; and it was there in the same year that John Bunyan became a definite member of his congregation.

Particular interest attaches to the contact of these two men, which seems to have begun in 1651 or 1652 ; for Bunyan's record of his experience from this time onward becomes detailed, and we get a vivid glimpse of the type of Christianity which Gifford and his Church presented. The immediate effect of its impact on Bunyan was to intensify his sense of sin, until he became convinced that he was damned. The narrative here shows unmistakable signs of the preacher's Calvinistic theology; and it would appear as though Gifford suggested to Bunyan many of those forms in which his "resistances" to conversion clothed themselves. Moreover, the despair into 
which he fell is accompanied by a marked lack of charity and of sympathy with the troubles of ordinary men, of which he is evidently in no way ashamed. For a year he absented himself from church, and passed through a period of great desolation. But he then returned to Mr. Gifford's ministrations, and found them as seasonable to his soul "as the former and the latter rains in their seasons." An experience of grace followed, which made him amenable to some regular instruction. The historical facts of Christ's Birth, Life, Death, and Resurrection came to have a meaning for him, as did the doctrine of the Incarnation; as a result of which he contracted a vehement distaste for the Quakers, whom he believed to deny these things, and for others of his contemporaries, whose sincerity he questioned. But, though Bunyan later looked back to this experience as marking a solid gain in his spiritual life, it was not permanent, and there followed many months of acute doubt, discouragement, and despair.

3. The first break in the cloud of despair occurred one day when Bunyan was " in a meeting of God's people." We do not know what kind of meeting it was; and the experience was not final in bringing peace to the subject. But it redirected the stream of his emotions and thoughts, and gave him a ground of hope which never forsook him again for long.

A survey of the social element in Bunyan's religious conflict is found, therefore, to reveal a very mixed colour in the "suggestions " to which he was exposed. That of the four poor women, and that of " the meeting of God's people" (so far as it went), seem to have been wholly beneficial; they made for inward unification and for charity towards others. We cannot pass so unqualified a verdict on the influence of Mr. Giffiord. Mr. Gifford's teaching represents the religious experience of a community, and its expression and systematization in a particular theological tradition. The vital element in this experience is the Supernatural revealed in cleansed and purified lives. But this very apprehension of God in Christ as the holiness of the converted individual has so preoccupied the subjects of it as to blind them to other aspects of experience; and the Divine justice is so presented as to terrify and repel all whose experience is not of the same intensity and focussed in the same factors. Hence Bunyan's years of despair, and of brooding over the unforgivable sin and other hard sentences of Scripture; hence, too, through the drying up of the veins of active sympathy, his lack of charity. His was a soul that could never have found God to be Love without great storm and trial within, all the more since he seems to have had his emotions of fear developed in his upbringing. But undoubtedly 
his experience of God as Love would have come more normally and met with less "resistance," had Mr. Gifford's suggestions sprung from a broader-based and more human theology, and had the community he represented been less rigorist in its conception of Faith. Here, if ever, in Bunyan was a man crying out for the ministry of reconciliation. Both parson and pastor failed him; and for want of one to do for him what Ananias did for St. Paul, he was condemned to long struggles " as in a miry bog," and to fruitless torments which need not have been his.

The history of John Bunyan, therefore, is an impressive witness not only to the reality and distinctness of religious experience, but also to the vital necessity that whatever is mediated in religious experience by human means should be rightly and truly mediated; that the community which preserves and transmits all that is communicable in religious experience should itself embrace every variety and aspect of that experience; and that this catholicity of experience should find expression in formuloe of adequate range to so vast a field, and be mediated in ways which will not misrepresent its inexhaustible richness. In other words, what is needed is an Authority co-extensive with the whole field of the relevantthat is, of Christian-experience; one which sacrifices none of the facts to premature theories, whether of a narrow theology or of a narrow scientific philosophy, and which insists on the ethical end of religion-namely, Charity-as the best criterion of Truth.

E. G. Selwyn.

\section{MAINTENANCE OF THE CLERGY IN THE EARLY CHURCH}

" LIKE the successors of the non-juring Bishops in the eighteenth century, or like the earlier preachers of the Wesleyan Methodists, the officers of the earlier Christian communities worked at trades, kept shops, took part in municipal affairs, and wore the dress of ordinary citizens."

This is the dictum of Dr. Hatch. In view of the present shortage of clergy and the inadequate maintenance of what clergy there are, it seems worth while to make some inquiry into the matter, in order to see what actually was the practice in the primitive Church, though, of course, it does not follow that the practice is suitable to these times, even if we can discover what it was. 